\title{
The New Trends and Strategies of College Ideological and Political Education in Internet Age
}

\author{
HE LINZHI
}

(Vocational and technical college of zhengzhou henan zhengzhou in henan province. 450121)

Keywords: internet age, ideological and political education, trends, strategies

\begin{abstract}
Modern network technology dramatically changed the learning and living conditions of current students, which brought significant challenges to the ideological and political education of students. Faced with the rapid development of the network, psychological and behavioral characteristics of college students has undergone great changes. Campus Ideological educators need to guide students to establish a correct view of the network based on students' psychological and behavioral characteristic. Also, set up web site for students ideological and political education, improve the effectiveness of moral education network, carry out promotion of network culture. It is needed to create early warning and assistance systems relying on students. During the ideological and political work, schools need networking mechanism need to be improved. By enhancing network services, occupy the position of ideological and political education in Internet age.
\end{abstract}

\section{Introduction}

In recent years, with the gradual development of the network and extensive application, dissemination of information of the Internet is continually accelerated, which not only deeply affected the thinking and behavior of college students, but also brings new tasks and challenges to ideological and Political Educators[1,2].

Currently, in order to properly complete the ideological and political education of college students, firstly, network technology and Ideological trends of students need to be understood. Based on investigations and analysis, constantly update the concept of ideological and political education, establish a new mechanism of ideological and political education of the Internet age[3,5]. Using the new ideological and political education, smoothly carried out ideological and political education. Explore new trends in Internet Technology ideological and political education for college students, and make the ideological and political education in the Internet age full of new vitality.

\section{Challenges for ideological and political education of college students brought by Internet}

Development Internet primarily brought the following challenges for ideological and political education of college students:

\subsection{The development of a network results in the ethical misconduct and values distorted of} college students

The existence of individualism, pragmatism and money worship in Internet can easily affect the judgment of right or wrong of students, which results in ethical misconduct. Since college students' values, outlook on life are in a growth process, some of the students are likely regard the network to entertainment, leisure-oriented hedonism, money worship seen as a mainstream culture. Not only that, there are all kinds of sex and violence and other negative culture, as well as the penetration of Western cultural values in the Internet, causing students in the choice of moral values to pursue more personality, emphasis on self, luxury pleasure, which is contrary to the socialist core values. Additionally, college students who are addicted to the virtual network are easily apathy and ignoring others. The anonymity, virtual and other characteristics of Internet, makes students reducing the requirements of their behavior of all aspects, and thus results in a lot of immoral behavior in the Internet. 


\subsection{Permeate values in Western countries in the field of culture and ideology is increasing}

In recent years, with the profound changes in the international and domestic situation, International hostile forces intensely struggle in the field of consciousness form field increasingly. The widely use of Internet allows the western hostile forces to implement a planned penetration of organized ideological and export of cultural using the platform of Internet. Students are confronted with a large number of Western culture and ideas, so that our network ideological defense is facing great challenges. Students' Internet ideological and political education is becoming more urgent.

\subsection{The freedom and openness of the network makes the information monitoring of college} out of control

In internet, there are a lot right, wrong, healthy or harmful, positive, negative information, the transmission of the information is free, regardless of geography, all organizations and individuals can publish information on the Internet. This unique mode of Internet facilitates our selection of information, constraints on college students' network behavior has great difficulty. Students behavior online cannot be grasped immediately.

\section{New trends and strategies of students ideological education in Internet age}

\subsection{Students' psychological and behavioral characteristics of the Internet age}

Students mainly have the following psychological and behavioral characteristics:

(1) Seek for knowledge Internet

Students in the Internet age, most of which are using the Internet as an intermediary to get the information based on their needs and interests, in terms of access to information into active information acquirer from the traditional passive recipients of information. In terms of access to information, the roles change from the traditional passive recipients of information into active information acquirer.

(2) Rebellious

In the network environment, the use of online media, college students obtain deeper and broader information, information transmission speed between the communicator and the recipient of more efficient but also has real-time, however, a variety of information in the network are fabrications, reversed, public gradually began to question the social responsibility of network media. This problem is not only detrimental to the credibility of network media, and directly led to the generation of rebellious college students. The doubts on Internet may result in irrational violence in Internet and this behaviors have features of fanaticism and less of responsibility.

(3) Need of identification

Internet is not only a way to disseminate information, but also provides a platform for university students two-way communication. The completely virtual cyberspace Students may leads to loneliness, helplessness and marginalization, which it is needed to adjust by the use of identity, so that achieves a physical and mental equilibrium. Identification of the Students' Network is essentially one of its value in the network environment of mutual recognition, mutual recognition of each other's values. But in real life, students' network identity is often malicious used, and become an industry.

(4) Self-realization

Internet provides students with a virtual space, in where students can freely create, play and reevaluation. However, there are a large number of network vulgar content, which strong affected the mainstream culture and brought a bad influence to college students. From Sister Lotus to showing off girl, from classic spoof to copy, In pursuing a self-realization in the network, students want to attract a lot of attention and ignore the significant negative.

(5) Anonymous

The feature of Internet hides the true identity of individuals in the virtual platform, which leads a lost of social responsibility. Students use role-playing, while maintaining a certain character to pursuit some sort of psychological compensation to reinvent themselves. 


\subsection{New trends and strategies of students ideological education in Internet age}

Conducting ideological and political education has become a new trend in the ideological and political education, but also has needs which is showing as following,

(1) Guide students to establish a correct view of the network

Widely used network greatly affects students ideology, making them more inclined to personal development, emphasis on self-development of personality. And even think that they can do whatever they want on Internet because of the virtuality. Therefore, in the ideological and political education students in the Internet age, teachers need to guide students to accurately understand the network, establish a correct network concept, and promote healthy and active network behavior.

(2) Set up website for ideological and political education

Setting up website for ideological and political education is a new trends under the background of Internet. Construction of ideological and political education of college students website is to build a station on the Internet. If there is no specific site as position, network ideological and political education of students will be difficult to achieve. Teachers need to carry out ideological and political work by fully use the Internet technology for students ideological and political education services, and make ideological and political education more attractive to students. Establishing political education exhibition site must fight against anti-party rhetoric illegal websites, and encourage more college students to love country, love community and love communism.

While constructing ideological and political education website for students, it is the needed to adapt to the characteristics of network competition, improve the attractiveness of ideological and political education websites. The success of a website is judged by the amount of traffic and access. If the site is not a popular political education, it must lack of attractiveness. Therefore, site must take full advantage of the Internet, change the boring traditional form of political education fundamentally with pictures, animations, video and other multimedia tools, so more and more students are interested in clicking Ideological website. In addition to increasing the attractiveness of the network, it is also needed to be close to nature. In the Internet age, ideological and political education for students, teachers are no longer a manager, but try heart friends for students. It is needed to improve the consciousness of the educated, so that students can achieve the development of individual active in self-management and self-education. By using the political education site Marxist theory and the Party's latest line, principles and policies introduced for students, students can be nurtured mind. Therefore, the network of ideological and political education must fully reflect the humane care, reflect the boring abstract image by concrete form to establish a good interaction between teachers and students.

(3) Improve the effectiveness of moral education network

Network with its equality, openness, freedom, etc., provides college students with a broad ideological education environment. In the ideological and political education, the network can fully perform its information-rich, interactive communication and other features, which provide excellent conditions for the favorable development of college students' moral education.

On ideological and political education web site for moral education, world of moral, legal forums, the spiritual homeland and other columns can be added, so that students can independently to express their ideas real on Internet, directly communicate with teachers, discuss encountered moral problems. As a result, teachers can better understand the ideological trend of college students and improve the effectiveness of moral education. Establish a special moral mailbox, so that part of the students who do not want to communicate to teachers directly can use the mailbox to the express the difficulties encountered, and teachers can use the anonymous feature of the Internet to fully meet the various needs of different college students , and get the support of university students. In addition, it is needed to carry out advanced models of moral education network , to fully use a wide range of network media, influential and attractive, good permeability and other characteristics, to carry out propaganda work for typical advanced education . Besides, students can also recommend some good moral education website and broad students' vision , improve their moral learning level. 
(4) Carry out a clear-cut cultural propaganda network

Culture is a carrier of great influence, which constantly transfer ideas and information. Construction of campus culture Internet, is not only a method to carry out ideological and political education network, but also to carry out ideological weapon for online education. Therefore, the method requires a variety of forms to create healthy network culture for undergraduate.

Firstly, fully take the home advantage, use the Internet to spread the principles and policies of the Communist Party of China, Deng Xiaoping Theory and the important thought of Three Represents to students and the disseminate the scientific concept of development theory, making the network ideological and political education has a more distinct political orientation.

Secondly, help students to establish ethnic cultural pride, use the excellent traditional culture and the outstanding cultural achievements for students to further establish pride in Chinese culture.

Thirdly, organize rich educational Internet activities. In order to broaden the variety, the competition of website, Internet moral debate competitions and other activities can be held. Effectively perform thoughtful, knowledgeable and interesting campus Internet culture activities, so that students can greatly improve the ideological and political awareness.

(5) Construct an ideological and political education team with an excellent quality

With the gradual development of computers, communication among students has changed dramatically. Students can easily access Internet using a mobile phone, resulting in a new phenomena of "Thought on the blog, knowledge from the web, emotion by message, friends in QQ”. The introduction of ideological and political education in the overall planning of the school network construction, combine the features of network and college students ideological and political education. In addition, in the construction of ideological and political education teams, not only need to strengthen the education of traditional ideological and political ideology, the traditional Chinese virtues and excellent culture, but also need to enhance efforts to organize a network of knowledge and ideological and political education so that teachers can master the related network technology in order to communicate with college students more effectively.

(6) Create an early warning and student aid system

In the ideological and political work, school students need to build a network of ideological and political warning and assistance systems for the healthy growth of students, including the following aspects:

Build a dynamic network early warning and assistance systems, which can solve the problem while the problem just appears. Specially set up psychological assistance website on the campus portal so that students can be more realistic self-awareness and self-regulation.

Make an Internet system for mental health warning and assistance, add special "smile online" part for psychological education website, so that students can be more realistic self-awareness and self-regulation

Establish early Internet warning and helping aid system for the poor students, use the survey results of students living conditions for poor students warning, and give temporary issuance.

Construct a student academic network of early warning and assistance system, establish students academic files, regular census. And alert the students who unsatisfied the results and help them to correct attitude towards learning.

(7) Improve networking mechanism, strengthen the network services

Build a complete mechanism of the Internet supervision. Build two teams for campus internet management, one is for the network information organization and supervision, the other is for the network construction and maintenance. Establish different work system to strengthen management, enhance network services, effectively complete the network of ideological and political education. Enhance student participation in the network of interest, and protect the campus network and on students' ideological and political education.

\section{Conclusion}

This paper analyzes several challenges to the students ideological and political education brought by the development of Internet. Based on psychological and behavioral characteristics of college 
students in Internet age, college ideological and political educators need to guide students to study, conduct ideological and political education to help students to establish a correct view of the network. Establish ideological and political education web site for college students to improve the effectiveness of moral education network, to carry out a clear-cut cultural propaganda network. Construct ideological and political education team with excellent quality to create early warning and student aid system. In the ideological and political work, schools need to improve networking mechanism, strengthen the network services, to occupy the position of ideological and political education in the Internet age.

\section{References}

[1] Yang Zhiqun. Challenges and Countermeasures of College Students' Ideological and political education in network era [J]. Journal of Changsha Tel \&amp; Tec Vocational College, 2012, (9): 60-63.

[2] Liu Peng. The challenges and Countermeasures of College Students' Ideological and political education in the Internet age [J]. Theroy Research, 2010, (2): 137-140.

[3] Zhang Jixia. Research on College Students' Ideological and political education in network era [J]. Journal of Jiangsu Teachers University of Technology, 2013, (3): 96-99.

[4] Zhou Liping, Hukou middle school. The faced opportunities and challenges and the countermeasures and analysis of the ideological and political work of college students in the Internet age [J]. Journal of Rizhao Polytechnic, 2012, (3): 18-21.

[5] Long Yuelian. The Countermeasure of College Students'Ideological and Political Education on Information Networking Era [J] Journal of Luohe Vocational and technical college, 2010, 9 (6): 